\title{
The Role of Leadership Negotiation Power and the Management of Communication Policies
}

Submitted 10/07/21, 1st revision 18/08/21, 2nd revision 30/08/21, accepted 26/10/21

\author{
Alexandros Koliopoulos ${ }^{1}$, Sotiria Triantari ${ }^{2}$, Eirini Stavropoulou ${ }^{3}$, \\ Konstantinos Spinthiropoulos ${ }^{4}$, Garefalakis Alexandros ${ }^{5}$
}

\begin{abstract}
:
Purpose: The leaders' communication skills, as they emerge in negotiations, contribute decisively to sustainability of business. This study identifies a set of characteristics, abilities, and skills that leaders possess and which, depending on the type of leadership, the character of their subordinates, and the achievement of goals at the workplace, emphasizes certain elements completing and supplementing the character of a leader to a greater or smaller extent that can lead to sustainability of business organizations.

Design/Methodology/Approach: Almost all characteristics scattered through leadership models enable us to formulate a proposed model aggregating these characteristics.

Findings: The study proposes the model of the leader-negotiator/mediator, modelled on the personality of an orator, possessing all the distinguishing features of a modern, demanding, and multi-faceted leader who aims both to achieve practical objectives at employee's satisfaction.

Practical Implications: Organizations and businesses want to grow in an ever-changing internal and external environment. The reasons that lead to the reorganization of companies and organizations vary. The role of leadership and in general the characteristics that govern leaders, plays an essential role for the smooth continuation of business activity. Originality/Value: This research provides a different approach to the role of leadership when dispute resolution is done using consensual mediation.
\end{abstract}

Keywords: Negotiation power, management communication policies, virtue ethics, sustainability.

JEL Classification: M10, M12.

Research type: Research article.

\footnotetext{
${ }^{1}$ University of West Macedonia, Department of Management Science and Technology, koliopoulosa@gmail.com;

${ }^{2}$ The same as in 1, striantari@uowm.gr;

${ }^{3}$ The same as in 1, stavreirini@yahoo.gr;

${ }^{4}$ The same as in 1, spinthiropoulos@gmail.com;

${ }^{5}$ Hellenic Mediterranean University, Department of Business Administration and Tourism;

agarefalakis@yahoo.gr;
} 


\section{Introduction}

An examination of leadership models points to the need for a contemporary upgrade and revision of the significance of Ancient Greek virtue ethics, which identifies the quality of man and a leader. The four critical Ancient Greek virtues, namely prudence, temperance, justice, and fortitude (Voudouris, 1996), appear dispersed insignificance or intrinsic to other characteristics of the dynamic personality of a leader, a person who serves as a praiseworthy, moral model for employees. The leader's personage is underscored by their morality more than any other abilities they may possess. Plato associated the moral integrity of man and virtue discourse with philosophical psychology and anthropology. In Aristotle's moral philosophy, readers note an evaluating ranking of moral principles and values over time, which are favoured and stand out depending on one's objective of purpose, on the one hand, and in relation with the framework wherein one appears as a moral actor, on the other (Voudouris, 1996). In this sense, this paper presents summary models of a leader included in the virtue ethics-based leadership model (Triantari, 2020) and presents the components making up the personality of the leader-negotiator/mediator.

The Model of an Authentic Leader: The key ethical value of an authentic leader is the honesty with which they must comport themselves and act. An authentic leader possesses self-awareness and a self-image that mainly derives from honesty, which adds another virtue: humility. An authentic leader expresses their motives and conduct about the institutional role they perform, and shares information with their subordinates, encouraging them to comprehend the process for their career development and personal growth at the workplace (Owens and Herkman, 2014). An authentic leader inspires subordinates, as does an ethical leader, who sets ethical expectations for all subordinates or team members (Stouten, van Dike and de Cremer, 2021).

The Model of an Ethical Leader: An ethical leader sets the values and influences the culture of the organization /enterprise. An ethically superior leader affects all management levels, providing guidelines for ethical conduct (Schaubroeck et al., 2012). An ethical leader, like an authentic leader, is honest and treats subordinates justly and equally. Their conduct motivates employees to achieve high performance and reduce conflicts, with corresponding progress in their interpersonal relationshipsan ethical leader, an authentic leader, and a charismatic leader share common characteristics.

The leader stands out for their allocentric values, making them a model of good conduct (Brown and Trevino, 2006). This type of leader reflects the most key of Aristotelian ethical virtues, the mean, which plays a predominant role, as it is the ability to avoid excess that may result from impulses and intense passions (Vegeti, 2000). Achieving the mean is the virtue and ability that confers upon leaders the supreme characteristic of being just and ethical while serving the common interest to serve their subordinates. 
The Model of a Servant Leader: This is a leader who tempers their desires, leaving personal interest behind to assist subordinates, making a positive contribution to their growth and development at the workplace (Van Dierendonock, 2011). Such leaders stand out for their active listening, empathy, persuasion, responsibility, guidance, and cultivation of their subordinates. A servant leader reflects the character and personality of an orator, significantly increasing the group's dynamism, bringing its members together in achieving common objectives, visions, and emotions. Temperance and emotional intelligence are attributes that make them stand out over others, with a view towards the common good, what is beautiful and fair for all $\mathrm{CHu}$ and Liden, 2011).

The Model of a Positive Leader: A positive leader highlights virtue which, according to Aristotle, manifests in practice through the aspiration of the subordinates to entrust their rights and interests to the leader, who will not exploit them (Simpson, 2007). Trust is the attribute that makes a leader reliable. Trust elevates the actor's psychological state, as it confers advantages to the leader-subordinate relationship, such as a. Favouring the joint undertaking of risks with the leader, when the latter indicates that this is a necessity; b-aiding the leader's active listening, who attentively listens to the information provided by the subordinates, placing them in a psychological state where they can speak freely (Detert and Burrsi, 2007), contributing towards increasing the dynamism of teams, which become more effective and efficient, going above and beyond in order to bring their task to completion; $d$. Enhancing productivity, as subordinates who trust their leader receive highperformance reviews (Colquitt, Scott and LePine, 2007).

Leaders who win their subordinates' trust stand out for three key attributes: a. their integrity and reliability, as evinced by their honest and candid conduct; b. soundness, meaning that the leader ensures the best for their subordinates, feeling emotions of teamwork and cohesion towards the team; c. communicativeness, meaning the leader has skills and interpersonal abilities and knowledge.

Reasons that frequently motivate subordinates to trust their leader include:

$>$ The leader's conduct and personality, mainly when they are accessible to subordinates;

$>$ The leader's culture and how closely it resembles the employees' or even the country's culture;

$>$ Critically timed circumstances are crucial for subordinates to trust their leader due to their conduct and way of thinking displayed during a specific period;

$>$ The leader's reliable and stable behavior can serve as a reason to restore trust when it is disrupted (Robbins and Judge, 2018).

The Model of a Coach Leader: A coaching leader possesses all the ethical and intellectual virtues that enable them to foster future leaders. They are mentors with a vision that they try to install in their subordinates, with a view of the common good. A coaching leader helps and supports less experienced subordinates or superiors and 
enables them to learn by participating in planning and shaping the vision. The leader and the subordinates, working together, prudently, and accurately set and realize short- and long-term goals, with everyone contributing to the achievement of the vision. The coaching leader creates a community of subordinates and has a catalytic effect on them, both professionally and psychosocially (Eby, Buits and Lockwood, 2004).

Virtue ethics-based leadership models entail values that identify the leader as an excellent mentor and negotiator who can foster and create leaders with equivalent mentoring and negotiating skills. These skills can have a decisive contribution, through their presence, to the workplace and change old habits and long-standing cultures. The coach leader model is quite like the negotiator leader model, thus providing the necessary conditions for establishing the negotiator leader's personality. Both the mentor and the negotiator leader possess ethical and intellectual virtues, with the pursuit of the mean and temperance at the forefront, prioritizing man's rational abilities. Temperance guides discretion, an equally crucial intellectual virtue, as the acts it results in are voluntary (Aristotle, 1362b). The ethical virtues contribute decisively to the behavior of both the mentor and the negotiator leader, while the intellectual virtues, which represent the rational part of the soul, direct the leader towards a true, realistic vision (Asimakopoulou, 2018).

The ethical virtues making up the personality of the coach leader have been found dispersed in virtue ethics-based leadership models and constitute the main aspects of the personality of the negotiator leader who, like the coach leader, stands out for their temperance, fairness, soundness, magnificence, gentleness, liberality, honor, friendliness, wittiness, magnanimity, honesty, self-control and leniency (Triantari, 2011; Lemonakis et al., 2017; Asimakopoulou, 2018).

These virtues are further augmented by communication skills, such as active listening, emotional intelligence, discretion, proper feedback, appropriate persuasiveness, and influence, supplementing the profile of the coach leader (Asimakopoulou, 2018), which serves as the standard for the negotiator leader (Saee, 2008).

\section{Literature Review}

\subsection{The Human-Work-Oriented Role of the Negotiator Leader}

The first and foremost attribute possessed by all leader types and defines leadership is persuasion, i.e., the leader's ability, like that of the orator, to convince, affect and influence their subordinates through their words and deeds (Triantari, 2019). The leader-orator's ability to persuade and influence underscores their ethical and social role. Leaders exercise their persuasive prowess based on the reliability and rectitude they inspire in their workers. The leader's personality, like that of the orator, emerges through a combination of logical and psychological persuasion (Amanchukwu et al., 2015). Through logical persuasion, leaders display their intellectual virtues, reasoning 
through their argumentation line, and rational thought through the establishment and implementation of goals and decision-making. Psychological persuasion is the leader's communication weapon, like that of the orator, as the leader uses emotional intelligence during interpersonal communication to understand their subordinates' needs, care for them as a group, whether individually or collectively, and satisfy their needs (Deichmann and Stam, 2015; Triantari, 2019). Temperance and emotional intelligence make for influential leaders if they think and act appropriately (Bazerman and Neal, 1982). They perceive others' emotions at the right time and can overrule their passions and emotions at a first level and their employees' passions and emotions at a second level (Carmeli, 2003).

The two-way relationship between discourse and character serves as the basis for the model of the leader-orator, who externalizes their image through the ethical quality of their discourse and the emotional, psychological attraction exerted on employees. This validates the modern theory of attribution, which does not focus on achieving objectives but the virtual reality that leaders create for their workers by embellishing their characteristics, giving the impression that they are intelligent, active, hardworking, etc., (Robbins and Judge, 2018). In an ideal workplace where everything functions well, certain imponderables trigger the intervention of an ideal leader, who has all the abilities that make them authentically ethical and practical (Perlmutter and Heenan, 1974).

One of the critical characteristics of the leader-orator is justice, whereby they distribute competencies and duties among subordinates fairly, without forgetting to reward them in proportion to the work they carry out. Aristotelian moral virtues outline the personality of a leader-orator, who prevails over a charismatic and transformational leader (Triantari, 2018) while imbued with the characteristics of mentor and negotiator leader. In terms of oratory and deliberative rhetoric Aristotle expounds on the communication skills of an orator, which concern practical and rational intent and good disposition, which underscore the orator's self-awareness and self-confidence (Aristotle, 1362b). Like an orator, a leader deliberates, discusses, and exchanges opinions and ideas, aiming at their subordinates' common purpose and prosperity (Triantari, 2018). Deliberative rhetoric in Aristotle's Rhetoric was the precursor to the modern form of negotiation and mediation, which are considered vital for dispute resolution due to the conflict often caused in both vertical and horizontal hierarchies and among organizations/enterprises in cases of conflicting interests (Triantari, 2018).

\subsection{The Modern Leader-Negotiator/Mediator}

In an era of various changes, economic globalization, the problem of ethics, and growing business ethics, a leader must be both a negotiator and a mediator. They are leaders possessing the attributes found in orators. The leader-orator is, in essence, a leader-negotiator, standing out for their persuasion, trust, flexibility, character, empathy, active listening, intelligence, impartiality, objectivity, honesty, reliability, 
composure, humor, respect, imagination, inventiveness, patience, and reticence (Triantari, 2018).

The attributes of a leader-negotiator/mediator underscore their character, which also stands out from their motives in the tactics they employ. A leader handles discourse and complete information as a negotiator because negotiation, much like mediation, is based on the exchange and effective use of information (Lewicki, Saunders and Minton, 2004). The logic and semantics of the message showcase the character of the leader-negotiator, who uses rhetorical prowess to guide the conflicted parties to what is in their common interest, stimulating their emotional intelligence and pursuing a mutually satisfactory agreement for both parties (Triantari, 2018). At this point, the leader-negotiator becomes the equivalent of the transformational leader. Their common ground is the model of transformative mediation, the most popular model in mediation. According to this model, the negotiator, as well as the mediator as a transformational leader, compels the conflicted parties to direct the process mutually, encourages them to proceed with their self-determination, supports and empowers them to overcome their interest and reach solutions that are mutually beneficial to both sides, so that both parties achieve their objectives (Iordanoglou et al., 2014).

The proposed model of a leader-negotiator/mediator focuses on the leader's personality and the dynamism of their communication ethics (Triantari, 2018). Communicative leaders care for their subordinates, wish to cooperate, and share, and stimulate subordinates' performance using fair and equitable practices in terms of pay, rewards, promotions, mobility, etc. The leaders' ethics reinforce their persuasiveness, and persuasiveness reinforces communication. The leader-negotiator/mediator prepares a strategy and sets goals, identifying the problem and calling on each side to understand what is being done and review the process (Acuff, 1993). The wording and argumentation of each side evince their experience, beliefs, and opinion regarding the negotiation. This overall framework once again alludes to the rhetorical reasoningargumentation reflecting the orator's ethical character, experience, beliefs, and motives (Triantari, 2020).

The leader-negotiator/mediator subverts conflicts and establishes an atmosphere of cooperation, communication, and understanding, externalizing the temperate leader following Aristotelian virtue ethics (Lewicki, Saunders, and Barry, 2004). The personality of the leader-negotiator/mediator points towards the multifarious leader of the future, i.e., the exceptional manager-leader who possesses ethical virtues and can face hazards and crises.

The contemporary leader, who is also a manager through the variety of characteristics and properties they possess, proves to be particularly productive, managerial, and effective when acting with temperance and sound judgment, focusing their communication skills on settling and managing conflicts, particularly in modern societies plagued by the health - economic crisis. One such case is the training of modern leaders-managers in negotiation and mediation, which are essential methods 
for political communication in the modern economies of joint-stock legal persons. The role of leader, whether at banking institutions or enterprises, has been assigned to leaders-managers (Lemonakis et al., 2019). Their power, emanating either from their prominent position within the organizational structure of the company (Luman, 1999) or due to their legitimation through the inherent structures of the operational procedure itself (Habermas, 1996), bestows upon them the "seductive authority" that allows them to negotiate with the prestige of a leader to resolve any disputes that arise (Brown and Trevino, 2006).

A survey conducted in January 2020 in Northern Greece, which has suffered dramatically due to the economic crisis, resulted in exciting information on the function of the negotiating process through the words of the actual protagonistsleaders who entered negotiations. The survey concerned the attitudes of businesses and banks towards consensual mediation as a form of alternative dispute resolution (during negotiations between them).

Questions were posed to the managers of four (4) "systemic" banks and two smaller banks (one independent and one cooperative bank), on the one hand, and the leadersmanagers of enterprises with a workforce capacity of ten (10) to one hundred (100) workers that were involved in financial products, on the other.

The survey resoundingly concluded that, while the overwhelming majority of bank managers and business leaders acknowledged the importance of the mediation process (33\% responded "quite important" and 46.66\% responded "very important" in the Banking sector, while $13.33 \%$ responded "quite important" and $66.66 \%$ responded "very important" in the business sector), the percentage where a mutually acceptable solution was reached through this process is low (33\% according to Bankers and just $20 \%$ according to businesspeople). Concerning the economic factors responsible for the low satisfactory results (objective lack of liquidity, already mortgaged real estate property, ambiguous investment environment, etc.), a significant percentage, namely $40 \%$, of Bank managers and $46.66 \%$ of business leaders-managers identified the dysfunction of the extra-judicial dispute resolution system as the critical factor at fault. In other words, it arose from the survey that leaders-managers believe that they would perform better in a complex financial environment if they could benefit from the support of a suitable institutional framework tool. Following the preceding conclusion, relevant training in banking mediation - negotiation was deemed vital by $80 \%$ of bank managers and $86.66 \%$ of business leaders-managers participating in the survey.

\section{Research Methodology}

The research objective is to explore the attitudes of businesses and banks towards alternative - out-of-court (OOC) - settlement resolution of disputes, naturally with emphasis placed on consensual mediation as an institutional procedure. Of course, other relevant areas are concurrently examined concerning percentages of success 
during negotiations concerning other investment products or the adequacy of specialized personnel and their training needs (Van Kleef, De Dreu, and Manstead, 2004). For this purpose, questionnaires were used, sent to the loan management divisions of the six (6) banks of Greece that answered them and to the financial divisions or financial directors of fifteen (15) Thessaloniki-based businesses, respectively, that were involved in one way or another - i.e., either as borrowers or as associates- with the banking above institutions. This led to a fascinating comparative study of the answers provided by the banking institutions and the business - companies involved. Similar questions were put to both sides, adapted to their object of interest. Their points of convergence and divergence on critical issues (see discussion) are impressive. A further research objective is to ascertain the conclusion being sought concerning the decade-long crisis in question. For this reason, the executives of both the banks and the companies asked to provide answers clarified that they were active during the past decade, i.e., from the year 2010 to date (see "Research conduct procedure" under $4 \mathrm{c})$.

The researcher researched throughout January 2020 in Thessaloniki. The questionnaires concerning the banking system research were submitted to the heads of loan granting management or settling of arrears at the Thessaloniki branches of the four "systemic" Banks (National Bank of Greece, Piraeus Bank, Eurobank, and Alpha Bank) as well as two smaller banks (Attica Bank and Pancretan Cooperative Bank). In the cases of the last two banks, the questionnaire was answered by the Thessaloniki branch managers. Fifteen key executives of the Banks were asked questions, when they were informed of the research object, they responded willingly, providing decisive assistance to the object of the study. Most executives belonged to Piraeus Bank due to its partnership with the Thessaloniki Bar Association.

Similarly, executives of fifteen Thessaloniki-based companies, to which the researchers, as a legal adviser and associated attorney, enjoyed direct access, answered the questionnaire concerning the value of alternative - OOC resolution of disputes with banking institutions. These are two enterprises active in the computer industry (Hardware \& software) and software production, two enterprises active in the production and manufacturing of plastics, two companies active in the production and manufacturing of paper products, three small industries, two companies involved in the sale of automobile goods, one translation agency and three smaller companies involved in retail sales.

The companies in question employ between two (2) and one hundred and eight (108) employees are all, as noted above, seated in Thessaloniki, and none constitutes a branch of a different company. It is also clarified that the research also explored the issue of settlement through a procedure for banking products strictly received by the company as a legal person and not by a partner thereof, including the President and CEO of the company, whether he or she held the majority of company shares or a majority stake in the share capital (Giannarakis and Garefalakis, 2011; Giannarakis et al., 2017). 
Before answering the questionnaire, all the banking executives involved confirmed that they have been active for at least the past decade in question. Similarly, the financial directors of the companies in question that responded to the questionnaire represented companies that were active during the last decade and faced the economic crisis. The respondents of the above companies provided answers swiftly (due to their familiarity with the researcher) and in writing via appointments. Half the banking executives preferred, following arrangements, to send their responses via e-mail. Nevertheless, following the researcher's exhortation, the respondents were free to make relevant comments and ascertainment, in fact often justifying and explaining the answers they provided. This fact proved very interesting throughout the research and the drawing of conclusions.

The questions are posed in such a manner that the respondent, having been asked in advance about all the relevant issues in question, gradually reaches the critical question, i.e., whether the mediation process will prove vital for the future of the banking system or the business world (depending on which side the questions were posed to). It was clarified to the respondents that any reference to alternative dispute resolution is a reference to OOC negotiation procedures and mediation. Initially, the respondents identified the Bank or enterprise where they work and then answered key questions concerning whether or not specialized ADR staff exists, whether ADR is implemented, which financial products it concerns, whether the training of negotiating parties is imperative, the percentage of success of OOC dispute resolution and the reasons for said percentage, the volume of cases being managed and the number of such cases made subject to the institutional procedure of mediation before reaching the central question concerning its importance and value.

The answers provided by either side are correlated and systematized to reach results from both sides' perspectives, which is the most impressive element of the research, i.e., the analysis of these data. The commentary on the answers leads to an overall result - an evaluation briefly summarized herein to draw a central, helpful conclusion.

\section{Discussion}

The following conclusions follow from the preceding, allowing for an interpretative approach to the position of statutory mediation and other OOC dispute resolution practices in the field of banking.

Both enterprises and banks believe that, while negotiation specialists are generally held in high esteem and are disposed to reach out to them, ultimately, such specialists are rarely called upon to complete the mediation procedure. Bank directors were unable to certify their staff's adequacy on OOC dispute resolution issues, despite stating that there is specialized staff for this purpose. However, the percentage of inclusion in mediation as an institution is meagre from both sides. Moreover, half the company executives questioned were not aware that there is such an instituted alternative procedure. The preceding indicates that we are in an embryonic stage of 
implementing the mediation procedure, at least in the business area examined. The OOC dispute resolution procedure appears to be particularly popular with both banks and entrepreneurs concerning their disputes. Both sides stressed the need for seamless cooperation between them.

One major problem that remains is 'red' business loans, which account for many negotiations between parties over other financial products (liquidity assistance, working capital, etc., investments in mutual funds, and term deposits). Many arrangements plan took place throughout the last decade-long crisis, not with the best results. Similarly, banks tried to negotiate the offer of investment or deposit products with enterprises, the results being exceptionally negative amidst economic instability and insecurity (Sariannidis et al., 2016).

In this overall investment environment, which is starting to become streamlined, the education - training of mediators to contribute to resolving disputes that arise are deemed crucial. This is acknowledged both by banks and enterprises, despite a tiny percentage that does not consider investing in this educational procedure to be particularly useful.

Bank directors worked on hundreds of cases of disputes between their banks and enterprises, seeking some arrangement - negotiation. Similarly, almost $80 \%$ of enterprise directors visited bank branches to settle their issues. When both were asked whether they trusted the instituted mediation procedure for their disputes above, the percentages barely reached 5\%, a fact indicative of the stage at which our country is in concerning the implementation of this institution.

However, in what percentage of cases was there a successful negotiation for any issues between the two sides involved? In addition to the very pessimistic percentage of $33.3 \%$ of problematic loan cases where a solution was reached, there is also the lower percentage of $20 \%$ identified by enterprises as the percentage of successful settlement of their loan agreements. This statistic is yet further proof why such a high percentage of the 'red' loans taken out by enterprises remain unsettled.

The lack of liquidity on the part of enterprises is the most decisive factor for the objective difficulty to resolve disputes arising between banks and enterprises. The latter attribute much responsibility to banks and their inflexibility (with an overwhelming majority of the latter, i.e., $80 \%$, denying said responsibility) and the lack of trust towards the methods of settlement and the so-called 'fine print' of agreements, with the banks, once again disputing this figure as having any effect on the failure to reach solutions. In any case, both sides agreed on the investment landscape being vague and insecure.

Finally, the researchers concluded that mediation was viewed as an instituted dispute resolution procedure enjoying the esteem and a sensation of hopeful expectations for enterprises and banks. There are gaps to be bridged, and specific dysfunctions were 
revealed and admitted, but the overwhelming majority of both sides involved and questioned agree on the need to find a framework for constructive negotiation through mediation. Without cooperation between banking institutions and companies, there can be no healthy entrepreneurship - and a prerequisite for healthy entrepreneurship is the financing of companies' investment plans by banks.

\section{Conclusions}

In this age of complexity, moral and economic crisis (due to the health crisis), and inequality, leaders must focus on conditions and examine events in-depth to pay more attention to processes, not results. With this condition met, the leadernegotiator/mediator is the multifarious leader who can manage the dualities of balance-imbalance, stability-chaos, agreements-disagreements, all of which go through complex processes inventiveness and improvisation in complex adjustment systems. Reshuffling is a common occurrence nowadays, and leaders require control, self-awareness, understanding, and proper verbal and non-verbal signification. In order to be multifarious, leaders require support in education, training, and seminars that concern such strategies and behaviors. A modern leader no longer needs individual activities but teamwork and interdependent actions within the broader workplace. The leader's actions and thoughts must be permeated by ethical values that ensure social and corporate responsibility.

Moreover, leaders must continuously seek and focus on innovative ideas and methods, constructive processes, and interactive behaviors that adapt to the complex environments we live in. The leader-negotiator/mediator is the type of multifarious person who, thanks to their characteristics, is crucial for the organization/enterprise's structure, strategy, and culture of the organization/enterprise. These are characteristics that serve as criteria for assessing a leader's maturity and level of commitment. The spread of the COVID-19 pandemic makes the multifarious personality (manager) even more demanding, as they will have to face suddenly social, ethical, and mainly economic problems, particularly after the uncertain progression of the pandemic. As a critical element of a leader's political communication, negotiation/mediation will serve a state to achieve within the Aristotelian meaning of the concept, in order to the adverse effects on the economy and extreme phenomena of psychological and emotional impact on people.

\section{References:}

Acuff, F.L. 1993. How to Negotiate Anything with Anyone Anywhere around the World. New York: American Management Association.

Amanchukwu, R.N., Stanley, G.J., Ololube, N.P. 2015. A Review of Leadership Theories, Principles and Styles and Their Relevance to Educational Management. Management, 5(1), 6-14. doi.org/10.5923/j.mm.20150501.02.

Aristotle. Nicomachean Ethics, 1st ed. Rhetoric, 1362b. 16, Cf. Mitropoulos, N, 2014:76. Asimakopoulou, V.C. 2018. Internal Emancipation. Coaching and Leadership, 1st ed. V.H. Asimakopoulou, Athens. 
Bazerman, M.H., Neal, M.A. 1982. Journal of Applied Psychology. J. Appl. Psychol., 1(67), 543-554.

Brown, M.E., Treviño, L. K.2006. Socialized Charismatic Leadership, Values Congruence, and Deviance in Work Groups. Journal of Applied Psychology, 91(4), 954-962. doi.org/10.1037/0021-9010.91.4.954.

Carmeli, A. 2003. The Relationship between Emotional Intelligence and Work Attitudes, Behavior and Outcomes: An Examination among Senior Managers. Journal of Management Psychology, 18(7-8), 788-813. doi.org/10.1108/02683940310511881.

Colquitt, J.A., Scott, B.A., LePine, J.A. 2007. Trust, Trustworthiness, and Trust Propensity: A Meta-Analytic Test of Their Unique Relationships with Risk Taking and Job Performance. Journal of Applied Psychology, 92(4), 909-927. doi.org/10.1037/0021-9010.92.4.909.

Detert, J.R., Burris, E.R. 2007. Leadership Behavior and Employee Voice: Is the Door Really Open? Academia Management Journal, 50(4). https://doi.org/10.5465/AMJ.2007.26279183.

Deichmann, D., Stam, D. 2015. Leveraging Transformational and Transactional Leadership to Cultivate the Generation of Organization-Focused Ideas. Leadership Q, 26(2), 204-219. https://doi.org/10.1016/J.LEAQUA.2014.10.004.

Eby, L., Buits, M., Lockwood, A., Simon, S.A. 2004. Protégés negative mentoring experiences: construct development and nomological validation. Personnel Psychology, 57 (2), 411-447. https://doi.org/10.1111/J.1744-6570.2004.TB02496.X.

Giannarakis, G., Garefalakis, A.E. 2011. The Content of Corporate Social Responsibility Information: The Case of Greek Telecommunication Sector. International Business Research, 4(3). https://doi.org/10.5539/ibr.v4n3p33.

Giannarakis, G., Garefalakis, A., Lemonakis, C., Konteos, G. 2017. The Drivers of Socially Responsible Stock Index: The Case of Dow Jones Sustainability Index World. Corporate Ownership and Control, 14(2), 173-180. https://doi.org/10.22495/COCV14I2C1P3.

Habermas, J. 1996. The Ethics of Communication, 1st ed., Alternative publications: Athens.

Hu, J., Liden, R.C. 2011. Antecedents of Team Potency and Team Effectiveness: An Examination of Goal and Process Clarity and Servant Leadership. Journal of Applied Psychology. https://doi.org/10.1037/a0022465.

Iordanoglou, D., Tsakarestou, B., Tsene, L., Ioannidis, K., Leandros, N. 2014. The Development of an Innovative Leadership Training Programme for European Young Professionals in Times of Crisis. Paper presented at the International Scientific Conference Economics and Management, Riga, Latvia.

Lemonakis, C., Batzanakaki, E., Steiakakis, S., Garefalakis, A. 2019. Exporting Activity at Turning Point: Continuity and Viability of Greek Manufacturing SMEs. International Journal of Corporate Finance and Accounting, 6(2). https://doi.org/10.4018/IJCFA.2019070103.

Lemonakis, C., Garefalakis, A., Giannarakis, G., Tabouratzi, E., Zopounidis, C. 2017. Innovation and SMEs Financial Distress during the Crisis Period: The Greek Paradigm. In The Greek Debt Crisis: In Quest of Growth in Times of Austerity. https://doi.org/10.1007/978-3-319-59102-5_10.

Lewicki, S., Barry, M. 2004. Instructor's Resource CD-ROM. Essentials of Negotiation, 3rd ed. Boston: McGraw-Hill Irwin.

Luhmann, N. 1999. Legalization through Process, 1st ed., K. Vathiotis, Ed. Kritiki: Athens. Owens, B.P., Hekman, D.R. 2012. Modelling How to Grow: An Inductive Examination of 
Humble Leader Behaviors, Contingencies, and Outcomes. Academia Management Journal, 55(4). https://doi.org/10.5465/amj.2010.0441.

Perlmutter, H.V., Heenan, D.A. 1974. How multinational should your top managers be?

Harvard Business Review, 52(6), 121-132.

Robbins, St., Judge, T.A. 2018. Organizational Behavior. Basic Concepts and Modern Approaches, 2nd ed.; Translation. A. Plataki, Ed. Athens.

Saee, J. 2008. Best Practice in Global Negotiation Strategies for Leaders and Managers in the 21st Century. Journal of Business Economics and Management, 9(4), 309-318. https://doi.org/10.3846/1611-1699.2008.9.309-318.

Sariannidis, N., Giannarakis, G., Zafeiriou, E., Billias, I. 2016. The Effect of Crude Oil Price Moments on Socially Responsible Firms in Eurozone. International Journal of Energy Economics and Policy, 6(2), 356-363.

Schaubroeck, J.M., Hannah, S.T., Avolio, B.J., Kozlowski, S.W., Lord, R.G., Treviño, L.K., Peng, A.C. 2012. Embedding ethical leadership within and across organization levels. Academy of Management Journal, 55(5), 1053-1078.

Simpson, J.A. 2007. Psychological Foundations of Trust. Current Directions in Psychological Science, 16(5), 264-268. https://doi.org/10.1111/j.1467-8721.2007.00517.x.

Stouten, J., Van Dijke, M., De Cremer, D. 2012. Editorial Ethical Leadership. An Overview and Future Perspectives. Journal of Personnel Psychology, 1, 1-6. https://doi.org/10.1027/1866-5888/a000059.

Triantari, S.A. 2020. Leadership Theories. From the Aristotelian Orator to the Modern Leader, 1st ed., K.M. Stamoulis, I. Arch. Harbantidis, Thessaloniki.

Triantari, S.A. 2019. Philosophy Magazine. Philos. Magazine of Science Favour. Parsimony, 1(20), 236.

Triantari, S.A. 2018. The Ethics of the Orator in Aristotle and Its Communicative Dimension. In Figura in Praesentia, Naka, T., Ed., K. Dina, Athens, p 556.

Triantari, S.A. 2018. From Conflict to Mediation. Mediation as a Communication Strategy and Policy, 1st edition. A. Stamoulis, Thessaloniki.

Van Dierendonck, D. 2011. Servant Leadership: A Review and Synthesis. Journal of Management, Review Article. https://doi.org/10.1177/0149206310380462.

Van Kleef, G.A., De Dreu, C.KW., Manstead, A.S.R. 2004. The Interpersonal Effects of Anger and Happiness in Negotiations. Journal of Personality and Social Psychology, 86(1), 57-76. https://doi.org/10.1037/0022-3514.86.1.57.

Vegeti, M. 2000. History of Ancient Philosophy, 1st ed. Dimitrakopoulos, I.D., Ed., Travlos, Athens.

Voudouris, K. 1996. The Unity of Greek Aretalogy and the Fundamental Virtues. Ethical Philosophy of the Greeks, 2nd ed. K. Voudouris, Athens.

\section{QUESTIONNAIRE - Tables and Commentary}

$1^{\text {st }}$ QUESTION POSED TO BANKS - Table 1.

Table 1. Which bank do you work for? answers (\%)

\begin{tabular}{lll}
\hline $\mathrm{A}$ & NATIONAL BANK OF GREECE & $20 \%$ \\
\hline $\mathrm{B}$ & PIRAEUS BANK & $40 \%$ \\
\hline $\mathrm{C}$ & EUROBANK & $20 \%$ \\
\hline $\mathrm{D}$ & ALPHA BANK & $6.6 \%$ \\
\hline $\mathrm{E}$ & ATTICA BANK & $6.6 \%$ \\
\hline $\mathrm{F}$ & PANCRETAN COOPERATIVE BANK & $6.6 \%$ \\
\hline
\end{tabular}


$1^{\text {st }}$ QUESTION POSED TO ENTERPRISES - Table 2.

Table 2. How many employees does the company you work for employ? answers (\%)

\begin{tabular}{lll}
\hline $\mathrm{A}$ & $1-10$ & $13.3 \%$ \\
\hline $\mathrm{B}$ & $11-25$ & $66.6 \%$ \\
\hline $\mathrm{C}$ & $26-50$ & $6.6 \%$ \\
\hline $\mathrm{D}$ & $51-100$ & $6.6 \%$ \\
\hline $\mathrm{E}$ & over 100 & $6.6 \%$ \\
\hline
\end{tabular}

Commentary: Most questionnaires were answered by the competent executives of Piraeus Bank due to the partnership between said Bank and the Thessaloniki Bar Association, followed by enterprises with a workforce of 11 to 25 employees. These enterprises are the driving force of economic activity in Thessaloniki, as the largest enterprises are seated in Athens.

$2^{\text {nd }}$ QUESTION POSED TO BANKS - Table 3.

Table 3. Does the bank employ specialized personnel involved in OOC dispute resolution methods?

\begin{tabular}{lll}
\hline ANSWERS: & YES & NO \\
\hline & $66.6 \%$ & $33.3 \%$ \\
\hline
\end{tabular}

$2^{\text {nd }}$ QUESTION POSED TO ENTERPRISES - Table 4.

Table 4. Have you contacted a specialist in order to institute conciliation proceedings with banking institutions?

\begin{tabular}{lll}
\hline ANSWERS: & YES & NO \\
\hline & $53.33 \%$ & $46.66 \%$ \\
\hline
\end{tabular}

Commentary: The following should be stressed, starting from the end: The majority of enterprises have contacted a specialist on banking issues, mainly, as they underlined, when there was a conflict with a bank and not when a bank intended to "sell" them a banking product under its own conditions. When asked to certify their adequacy on issues pertaining to OOC dispute resolution, on the other hand, bank directors responded either that "it is a matter of experience" or that "there are no provisions for such certification", in contrast to a Piraeus Bank executive who produced a certified mediator certificate.

Nevertheless, the majority of bank directors did not hesitate to state that "there is specialized staff for this purpose" at their institutions. This contradiction does not impress those in the know. At this point, the research took the opportunity to underline the dreadful outcome for 80,000 borrowers of loans in Swiss francs, the overwhelming majority of who took out loans to purchase a first residence, which ended up as a purely investment product exposed on the foreign exchange markets. At that point, all banking institutions and the "systemic" banks in particular "sold" specialized information from ostensibly adequately trained associates, who proved to be not only criminally inadequate but also fundamentally uninformed.

Below can be found the provisions of Act No 25001/2002 (Government Gazette, Series I, Issue 277/2002) of the Governor of the Bank of Greece, issued with the authorization of Article 18(5) of Law 2076/1992 (as in force until repealed pursuant to Article 92(1) of Law 3601/2007) and, therefore, is in effect as substantive law amending and codifying the provisions concerning the disclosure requirements of credit institutions operating in Greece to retail customers with respect to terms and conditions governing the provision of bank services. In accordance with the general principles laid down in paragraph A of the Act of the Governor of 
the Bank of Greece in question, credit institutions are obligated, inter alia, to duly inform their retail customers of the nature and characteristics of the products and services offered and, in general, of the terms and conditions governing bank transactions, and to ensure the proper training of their employees charged with providing specific information to the retail public. The content of the minimum disclosure required, aiming at enabling customers, before entering into an agreement, to clearly understand the characteristics of the services and products on offer, when such products and services are not customized and, hence, negotiable on a bilateral basis, is set forth in paragraph B of the same Act of the Governor of the Bank of Greece and is specified according to the type of banking product (deposits, lending, etc.) With specific regard to loans in foreign currency or with a foreign currency clause, the Act enacts an obligation of disclosure on risks arising from exchange rate volatility (paragraph B, No 2, sub-paragraph $\mathrm{x}$ ). While the specific content of this disclosure obligation is not further specified in the aforesaid Act, the above requirement does not simply and solely constitute a reminder of the possibility of a change in exchange rate, but must enable borrowers to assess, on the basis of clear and understandable criteria, the financial consequences, and changes that such a likelihood would entail for them.

More specifically, the above provision enacting the disclosure obligation in question (paragraph B, No 2, sub-paragraph $\mathrm{x}$ ) must be interpreted in light of the provisions of Article 288 of the Hellenic Civil Code, whereby, as is accepted (Supreme Court Judgment 1352/2011; Athens Court of Appeal Judgment 1403/2015, 'NOMOS' legal database), banks have enhanced responsibilities in the performance of their financing operations and are obligated to safeguard the interests of the creditors they finance, since the credit relationship, as a legal relationship of particular trust between parties imposes a fiduciary obligation of protection on behalf of banks with regard to the interests of their customers in order to avoid excessively onerous consequences for them, and its specific content must be specified on the basis of the provisions of par. B No 1 of the aforesaid Act of the Governor of the Bank of Greece. According to the foregoing, borrowers must be notified with regard to loans in foreign currency and the risk arising from exchange rate volatility by suitably trained staff holding the suitability certificate provided for under Article 14 of Law 3606/2007; similarly, before 'christening' an executive as a specialist, the bank should identify how said specialization is proven.

$3^{\text {rd }}$ QUESTION POSED TO BANKS - Table 5.

Table 5. Does the bank employ specialized personnel involved in the instituted procedure of mediation?

\begin{tabular}{llll}
\hline ANSWERS: & YES & NO & I do not know \\
\hline & $6.6 \%$ & 86.9 & $6.6 \%$ \\
\hline
\end{tabular}

3rd QUESTION POSED TO ENTERPRISES-Table 6.

Table 6. Have you specifically contacted an accredited mediator so as to be made subject to this instituted procedure in order to negotiate with banking institutions?

ANSWERS:

Commentary: The results concerning this specific implementation of mediation as an institution are interesting: The percentage of inclusion in mediation is very low, while there was one case of a banking executive who was unaware of whether the bank had an accredited mediator. Very few enterprises, on the other hand, have oriented themselves towards this dispute resolution procedure. In fact, it is stressed that at least half the company executives 
who answered the questionnaire were unaware that there is such an instituted alternative procedure. Moreover, all respondents stated to the researcher that there had been no such approach - proposal on behalf of the bank for inclusion in such a procedure. The foregoing clearly indicate that we are in the early stage of implementation of the mediation procedure, at least in the field of banking disputes and specifically those concerning problems facing enterprises.

$4^{\text {th }}$ QUESTION POSED TO BANKS - Table 7.

Table 7. Do you, as a Bank, aim at subjection to an OOC dispute resolution procedure?

\begin{tabular}{lll}
\hline ANSWERS: & YES & NO \\
\hline
\end{tabular}

$4^{\text {th }}$ QUESTION POSED TO ENTERPRISES - Table 8.

Table 8. Do you, as a Company, aim at subjection to an OOC dispute resolution procedure?

\begin{tabular}{lll}
\hline ANSWERS: & YES & NO \\
\hline
\end{tabular}

Commentary: This is a rare example of full consensus on the matter. The entire sample of the respondents, 30 bank executives and the corresponding directors of the enterprises in question, did not hesitate to express their aim to resolve disputes between them out of court. In fact, they stressed that the objective is seamless cooperation rather than involvement in courtroom proceedings, which are both time-consuming and costly.

$5^{\text {th }}$ QUESTION POSED TO BANKS - Table 9.

Table 9. Categorise the bank's financial products you were called to settle by name and percentage in terms of your transactions with enterprises.

\begin{tabular}{lll}
\hline \multicolumn{2}{c}{ Answers (by product) } & Answers (as a percentage) \\
\hline $\mathrm{A}$ & BUSINESS LOANS & $80 \%$ \\
\hline $\mathrm{B}$ & $\begin{array}{l}\text { LIQUIDITY ASSISTANCE PRODUCTS } \\
\text { Working capital, current accounts, import financing, } \\
\text { leasing financing, fixed asset financing, green } \\
\text { entrepreneurship }\end{array}$ \\
\hline $\mathrm{C}$ & $\begin{array}{l}\text { INVESTMENT PRODUCTS (bond funds, cash } \\
\text { management, mixed funds, equity funds) }\end{array}$ & $66.6 \%$ \\
\hline $\mathrm{D}$ & TERM DEPOSITS & $6.6 \%$ \\
\hline $\mathrm{E}$ & OTHER & $6.6 \%$ \\
\hline
\end{tabular}

$5^{\text {th }}$ QUESTION POSED TO ENTERPRISES - Table 10.

Table 10. Categorize the financial products regarding which you entered transactions and needed to settle by name and percentage in terms of your transactions with Banks.

\begin{tabular}{|c|c|c|}
\hline & Answers (by product) & Answers (as a percentage) \\
\hline $\mathrm{A}$ & BUSINESS LOANS & $93.33 \%$ \\
\hline $\bar{B}$ & $\begin{array}{l}\text { LIQUIDITY ASSISTANCE PRODUCTS } \\
\text { Working capital, current accounts, import financing, } \\
\text { leasing financing, fixed asset financing, green } \\
\text { entrepreneurship }\end{array}$ & $66.6 \%$ \\
\hline $\bar{C}$ & $\begin{array}{llll}\text { INVESTMENT PRODUCTS (bond } & \text { funds, cash } \\
\text { management, mixed funds, equity funds) } & & \\
\end{array}$ & $0 \%$ \\
\hline $\mathrm{D}$ & TERM DEPOSITS & $6.6 \%$ \\
\hline
\end{tabular}


\begin{tabular}{lll}
\hline E OTHER & $0 \%$
\end{tabular}

Commentary: The tables clearly encapsulate the economic damage wrought by the so-called 'red' (i.e., non-serviceable) bank loans and, in particular, those of the business sector which, according to Bank of Greece data, amount to close to 70 billion euros and account for $42 \%$ of all loans $[43,44,45]$. Banks are called upon to settle - negotiate mainly for these products over others and, similarly, the overwhelming majority of enterprises aim to settle these loan products. Liquidity assistance products follow, with working capital being the main thrust, as both sides spontaneously stated to the researcher that while it was granted for investment purposes, it was consumed for other needs of current inflexible business obligations, thus it also became subject to arrangements and negotiations, as enterprises were unable to pay the amounts due in part or in whole.

Settlement and arrangement plans were discussed during the crisis, even on a monthly basis. All the stakeholders experienced this situation quite intensely, as they stated. In the toxic investment environment of the last decade (in contrast to the decade previous to that, when Banks competed with each other over which would offer the most profitable investment product in order to raise and attract investor capital), investments in mutual funds and term deposits collapsed. It is noteworthy that none of the company directors stated that their company showed interest during the past decade in investment products, and that all retained their current liquidity for upcoming needs $[46,47,48,49,50]$.

$6^{\text {th }}$ QUESTION POSED TO BANKS - Table 11.

Table 11. Do you believe that the training of specialized - accredited mediators would make an effective contribution towards the process of OOC dispute resolution?

\begin{tabular}{llll}
\hline ANSWERS: & Yes, definitely & Somewhat & Not at all \\
\hline & $80 \%$ & $13.3 \%$ & $6.6 \%$ \\
\hline
\end{tabular}

$6^{\text {th }}$ QUESTION POSED TO ENTERPRISES - Table 12.

Table 12. Do you believe that the training of specialized - accredited mediators would make an effective contribution towards the process of OOC dispute resolution?

\begin{tabular}{llll}
\hline ANSWERS: & Yes, definitely & Somewhat & Not at all \\
\hline
\end{tabular}

Commentary: It clearly arises from the foregoing that the education - training of mediators in order to contribute to dispute resolution (mainly due to 'red' loans between Banks and enterprises) is considered important and crucial. However, a small number of executives were not at all optimistic regarding dispute resolution via mediation, stating that the education of persons not well versed in the subject is "a waste of time and money", as they characteristically stated.

$7^{\text {th }}$ QUESTION POSED TO BANKS - Table 13.

Table 13. During the last decade at issue, how many loans (i.e., in arrears) did you manage on an annual basis?

\begin{tabular}{lll}
\hline & Answers (by number) & Answers (as a percentage) \\
\hline $\mathrm{A}$ & $0-50$ & $6.6 \%$ \\
\hline
\end{tabular}




\begin{tabular}{lll}
\hline $\mathrm{B}$ & $51-100$ & $6.6 \%$ \\
\hline $\mathrm{C}$ & $101-200$ & $40 \%$ \\
\hline $\mathrm{D}$ & $201-400$ & $46.6 \%$ \\
\hline $\mathrm{E}$ & 400 and above & $0 \%$ \\
\hline
\end{tabular}

$7^{\text {th }}$ QUESTION POSED TO ENTERPRISES - Table 14.

Table 14. How frequently did you contact banking institutions to settle your loan agreements?

\begin{tabular}{lll}
\hline & Answers (by frequency) & Answers (as a percentage) \\
\hline $\mathrm{A}$ & NEVER & $6.6 \%$ \\
\hline $\mathrm{B}$ & RARELY & $0 \%$ \\
\hline $\mathrm{C}$ & SOMETIMES & $13.3 \%$ \\
\hline $\mathrm{D}$ & OFTEN & $20 \%$ \\
\hline $\mathrm{E}$ & VERY OFTEN & $60 \%$ \\
\hline
\end{tabular}

Commentary: Almost 90\% of bank directors were involved in settling and managing over 100 problematic loan agreements that had fallen into payment arrears. In fact, the majority of these agreements concern between 200 and 400 loans, indicating both the problem that has arisen and the workload created. This also explains the number of companies visiting banks, with $80 \%$ of company respondents stating that they visited their associated bank often or very often to settle their outstanding loan issues.

$8^{\text {th }}$ QUESTION POSED TO BANKS - Table 15.

Table 15. In how many of the above cases you were asked about was the instituted procedure of mediation implemented?

\begin{tabular}{lll}
\hline & Answers (as a percentage) & Answers (as a percentage) \\
\hline A & 1 to $5 \%$ of the cases examined & $100 \%$ \\
\hline B & 6 to $10 \%$ of the cases examined & $0 \%$ \\
\hline C & 11 to $20 \%$ of the cases examined & $0 \%$ \\
\hline D & 21 to $50 \%$ of the cases examined & $0 \%$ \\
\hline
\end{tabular}

$8^{\text {th }}$ QUESTION POSED TO ENTERPRISES - Table 16.

Table 16. With regard to the aforesaid cases of overdue debts, were you made subject to the instituted procedure of mediation?

ANSWERS:

$\begin{array}{ll}\text { YES } & \text { NO } \\ 6.6 \% & 93.3 \%\end{array}$

Commentary: In this case, the numbers speak the blunt, cynical truth. Taking the above tables into consideration, the instituted procedure of mediation is in an embryonic stage in Greece: banks do not implement it, while private enterprise does not prefer it or may underestimate it. The results are illuminating, indicating a percentage of nearly $5 \%$ for those made subject to the procedure, if we correlate the answers of both respondent sides.

$9^{\text {th }}$ QUESTION POSED TO BANKS - Table 17.

Table 17. What percentage of the financial loan products (non-serviceable loan agreements overdue debts of any type) made subject to negotiation - mediation by an enterprise or your Bank resulted in a mutually acceptable solution?

Answers Answers (as a percentage)




\begin{tabular}{lll}
\hline A & A MUTUALLY ACCEPTABLE SOLUTION WAS & $33.3 \%$ \\
& REACHED \\
\hline B & A MUTUALLY ACCEPTABLE SOLUTION WAS & $66.6 \%$ \\
& NOT REACHED
\end{tabular}

$9^{\text {th }}$ QUESTION POSED TO ENTERPRISES - Table 18.

Table 18. What percentage of your enterprise's financial loan products (non-serviceable loan agreements - overdue debts of any type) that were made subject to negotiation - mediation either at your initiative or at the bank's initiative resulted in a mutually acceptable solution?

\begin{tabular}{lll}
\hline & Answers & Answers (as a percentage) \\
\hline A & $\begin{array}{l}\text { A MUTUALLY ACCEPTABLE SOLUTION WAS } \\
\text { REACHED }\end{array}$ & $20 \%$ \\
\hline B & $\begin{array}{l}\text { A MUTUALLY ACCEPTABLE SOLUTION WAS } \\
\text { NOT REACHED }\end{array}$ & $80 \%$ \\
\hline
\end{tabular}

Commentary: These research results gave rise to even more questions. Initially, all forms of negotiation were artificially included in the question, as it was proven that use of accredited mediation was limited. However, what is the reason for the monumental failure to reach solutions through negotiation procedures, even though they are esteemed and pursued by stakeholders? (Lenders - borrowers).

What hinders their effectiveness? It should be noted that in addition to the very pessimistic percentage of $33.3 \%$ of problematic loan cases where a solution was reached, there is also the even lower percentage of $20 \%$ identified by enterprises as the percentage of successful settlement of their loan agreements. This statistic is yet further proof of why such a high percentage of the 'red' loans taken out by enterprises remain unsettled and no government to date has found an effective solution to this issue.

$10^{\text {th }}$ QUESTION POSED TO BANKS - Table 19.

Table 19. In your opinion, what is the reason for this high rate of failure?

\begin{tabular}{lll}
\hline & Answers & Answers (as a percentage) \\
\hline A & $\begin{array}{l}\text { OBJECTIVE LACK OF LIQUIDITY ON THE PART OF } \\
\text { ENTERPRISES }\end{array}$ & $66.66 \%$ \\
\hline B & ABSENCE OF ASSETS - NO RISK OF SEIZURE & $66.66 \%$ \\
\hline C & $\begin{array}{l}\text { LACK OF CONFIDENCE IN THE BANK'S PRACTICES } \\
\text { AND THE SO-CALLED 'FINE PRINT' }\end{array}$ & $26.66 \%$ \\
\hline D & $\begin{array}{l}\text { DYSFUNCTIONAL OOC DISPUTE RESOLUTION } \\
\text { SYSTEM }\end{array}$ & $40 \%$ \\
\hline E & $\begin{array}{l}\text { SHORTAGE OF SPECIALISED - TRAINED STAFF } \\
\text { RESOLVING SUCH DISPUTES (on both Sides) }\end{array}$ & $26.66 \%$ \\
\hline F & INFLEXIBILITY ON THE PART OF BANKS & $20 \%$ \\
\hline G & VAGUE INVESTMENT LANDSCAPE - ABSENCE OF & $53.33 \%$ \\
& HOPE FOR RECOVERY & \\
\hline
\end{tabular}


$10^{\text {th }}$ QUESTION POSED TO ENTERPRISES - Table 20.

Table 20. In your opinion, what is the reason for this high rate of failure?

\begin{tabular}{lll}
\hline \multicolumn{2}{l}{ Answers } & Answers (as a percentage) \\
\hline $\mathrm{A}$ & $\begin{array}{l}\text { OBJECTIVE LACK OF LIQUIDITY ON THE PART } \\
\text { OF ENTERPRISES }\end{array}$ & $86.66 \%$ \\
\hline $\mathrm{B}$ & ABSENCE OF ASSETS - NO RISK OF SEIZURE & $33.33 \%$ \\
\hline $\mathrm{C}$ & $\begin{array}{l}\text { LACK OF CONFIDENCE IN THE BANK'S } \\
\text { PRACTICES AND THE SO-CALLED 'FINE PRINT' }\end{array}$ & \\
\hline $\mathrm{D}$ & $\begin{array}{l}\text { DYSFUNCTIONAL OOC DISPUTE RESOLUTION } \\
\text { SYSTEM }\end{array}$ & $46.66 \%$ \\
\hline $\mathrm{E}$ & $\begin{array}{l}\text { SHORTAGE OF SPECIALISED - TRAINED STAFF } \\
\text { RESOLVING SUCH DISPUTES (on both sides) }\end{array}$ & $46.66 \%$ \\
\hline $\mathrm{F}$ & INFLEXIBILITY ON THE PART OF BANKS & $80 \%$ \\
\hline $\mathrm{G}$ & VAGUE INVESTMENT LANDSCAPE - ABSENCE & $53.33 \%$ \\
& OF HOPE FOR RECOVERY & \\
\hline
\end{tabular}

Commentary: We focus on the diametrically opposed perspectives - answers provided by the two respondent sides on these issues. While the lack of liquidity of enterprises is a key factor for the objective difficulty to resolve disputes, it is cited as a reason far more on the part of enterprises than that of Banks. In fact, twice the number of banks than enterprises perceive the absence of own assets of the company in question as a negative factor for achieving a settlement, in contrast to the views of enterprises. The answers given by their directors essentially accuse banks of their inflexibility; however, banks accept this factor as impeding solutions only in $20 \%$ of cases. Banks also believe that the lack of trust towards them does not play a crucial role in the outcome of a negotiation, in contrast to enterprise directors, more than $50 \%$ of whom stated that there is a lack of trust in bank practices and their 'fine print'. The vague investment climate in the future is a factor contributing to the inability to reach a viable solution for both sides.

$11^{\text {th }}$ QUESTION POSED TO BANKS - Table 21.

Table 21. How decisive a factor is the institution of mediation and its conduct by accredited mediators for the management of financial problems between the Bank and enterprises?

\begin{tabular}{lllll}
\hline ANSWERS: & Not at all & A little & Somewhat & Very \\
\hline & $6.6 \%$ & $13.33 \%$ & $33.33 \%$ & $46.66 \%$ \\
\hline
\end{tabular}

12th QUESTION POSED TO ENTERPRISES - Table 22.

Table 22. How important is the establishment of mediation in the investment environment of banks transacting with enterprises?

\begin{tabular}{cllll}
\hline ANSWERS: & Not at all & A little & Somewhat & Very \\
\hline & $6.6 \%$ & $13.33 \%$ & $13.33 \%$ & $66.66 \%$ \\
\hline
\end{tabular}

Commentary: The research ended with the key question concluding the questionnaire: How important is the establishment of mediation in the investment environment of banks transacting with enterprises? Will it help in the future in this direction? Both respondent sides seized the opportunity at this point to stress the importance of resolving the burning question of 'red' loans for the development of healthy entrepreneurship.

The issue is exceptionally complex and touches on matters beyond the research scope, such as the intermingling of powers and the presidents of banking institutions for the extension of loans 
to 'favourite' enterprises without appropriate insurance risk safeguards. This reference was made by two respondent enterprises and is brought up simply in order to underline the fact that the issue cannot be solved by 'waving a wand' but depends on many factors. Is instituted mediation one of these factors in practice? According to the research conducted, it is - and this prospect is widely accepted by the overwhelming majority of bank and enterprise officials questioned. In the researcher's view, this is a step in the right direction. 